\title{
Climate-Smart Agricultural Extension Service Innovation Approaches in Uganda: Review Paper
}

\author{
Benson Turyasingura, ${ }^{1, *}$, Petros Chavula ${ }^{2}$ \\ ${ }^{1}$ Faculty of Agriculture and Environmental Sciences, Kabale University, PO Box 317, Kabale, Uganda. \\ ${ }^{2}$ Department of Climate-Smart Agriculture, Haramaya University, Haramaya, Oromia, Ethiopia.
}

How to cite this paper: Benson Turyasingura, Petros Chavula. (2022) Climate-Smart Agricultural Extension Service Innovation Approaches in Uganda: Review Paper. International Journal of Food Science and Agriculture, 6(1), 35-43. DOI: 10.26855/ijfsa.2022.03.006

Received: December 3, 2021

Accepted: December 27, 2021

Published: February 8, 2022

"Corresponding author: Benson Turyasingura, Faculty of Agriculture and Environmental Sciences, Kabale University, PO Box 317, Kabale, Uganda.

Email: bensonturyasingura@gmail.com

\begin{abstract}
Agriculture is anticipated to remain the economy's backbone for the foreseeable future, with agricultural operations employing a large majority of Uganda's work force $72 \%$. The aim of this review was to assess the agriculture extension and advisory services; brief description of agriculture extension and advisory service system in Uganda focusing on typology providers, dominant models used and target groups; providing examples of agriculture extension and advisory services related to climate smart agriculture with specific adaptation and mitigation and identifying and discussing the innovative approach and methods being used by different service providers in climate smart related extension. Farmers' groups, government organizations, non-governmental organizations, commercial organizations, and universities are among the typologies employed in Uganda's agriculture extension service. The agriculture extension and advisory services related to climate smart agriculture were integrated soil fertility management, crop rotation, cover crops and green manure, rotational grazing, seasonally adapted planting time and agroforestry systems. The innovative approach and methods being used by different service providers in climate smart related extension included extension methods for transfer of climate knowledge, training and visit extension and unified extension approaches, climate awareness mass media campaigns, ICT supported farmers in adaptation and mitigation, farmer field school and climate-smart villages. It was concluded that climate-smart extension approaches need to be considered as part of a broader set of adaptation measures and policies for agricultural systems at a range of scales through ICT integration. The study recommended for a strategic plan for women engagement in agriculture extension services by the Ugandan government.
\end{abstract}

\section{Keywords}

Advisory Service, Climate Smart Village, Extension, approach, Uganda

\section{Introduction}

Agriculture is anticipated to remain the economy's backbone for the foreseeable future, with agricultural operations employing a large majority of Uganda's work force (72 percent), and the industry accounting for around 25.9\% of GDP [1, p. 190]. It accounts for $1 / 2$ Uganda's export profits, primarily through coffee [2, p. 27]. However, the development of commercial farming for lucrative export markets, commercial farming's percentage of overall production is still small [3]. More than 95 percent of the country's cultivated crops come from rain-fed agriculture [4].

Uganda is a landlocked East African country with a land area of around 241,500 square kilometers that has borders with the Democratic Republic of Congo, Kenya, Rwanda, Sudan, and Tanzania [5]. Its geography is defined by a large supply of natural resources, moderately fertile soil, and a diverse range of wildlife and flora [6]. Further, the nation is 
rich in water resources, with around 18 percent of its surface area being formed of water bodies or wetlands [7]. The largest lake on the African continent, Lake Victoria, is located on Uganda's southeastern border [8]. The nation is organized into four regions: northern, eastern, western, and central, with 135 districts in total [9, p. 8].

Over the last two or more decades, global agricultural extension and advisory systems have experienced significant modifications [10]. The success of the Green Revolution in increasing global food supply, the expansion of commercial agriculture, particularly in richer countries, and trade liberalization, all of which are contributing to a rapidly changing global food system, are all factors in these changes [11].

Agricultural extension and consultancy services are intended to boost output while simultaneously addressing social and economic development objectives [12]. It also addresses issues such as the long-term viability of the production system, as well as improved quality of life and rural livelihoods. Many African countries, including Uganda, have extended their extension and consultancy services to include governmental, non-profit, and private sector enterprises that are an important component of the agricultural value chain, notably in western Uganda.

\section{Literature Review}

\subsection{Brief Description of Agriculture Extension and Advisory Service System in Uganda}

(1) The Historical Evolution of AEAS in Uganda

In the last forty years, Uganda has used a variety of agricultural extension measures such as regulatory, advisory, and academic methods to distribute innovations to communities [13].

According to [14], the variety of developmental phases in Ugandan agricultural extension, including (1) Regulatory service, which lasted from 1920 to 1956; (2) Education Advisory: 1964-1971; (3) Dormancy: 1972-1981; (4) Recovery: 1982-1999; (5) Educational (1992-1996); (6) Participatory (1997-1998); (7) Decentralized Education from 1997 to 2001; now, agricultural services are provided through contract extension systems, as shown in the table below (see Table 1 below).

Table 1. Ugandan agriculture extension services, typology, dominant models and their target groups

1920-1956 Through chiefs and expatriate field officials, materials and instructions on how to raise crops were distributed.

1956-1963 Extension via progressive farmers; technical guidance and assistance in the form of inputs.

1964-1972 Advisory education and commodity approach.

1972-1980 Dormancy; Disruption of economy, political instability; civil war.

1981-1991 Restoration of basic services; improved infrastructure.

1992-1998 Agricultural Extension Programme (AEP) of the government, with a 'single extended strategy' and the 'Training \& Visit system' being phased in to 27 districts; criticisms of extension public services.

The 'Village Level Participatory Approach' (VLPA) was implemented into the public extension service and then placed on hold after World Bank criticism; The Agricultural Sector Support Programme, which is funded by DANIDA, aids farmer groups in the delivery of advisory services.

The National Agricultural Advisory Services (NAADS) program is being created, while the Policy for the Moderni-

1999-2001 zation of Agriculture (PMA) is being completed. The provision of consultancy services by decentralized farmer organizations is encouraged. The National Agricultural Research Organization (NARO) has started its Outreach Program.

2001

Parliament passes the NAADS Bill; the NAADS program is tied to a larger decentralization of capacity-building efforts.

According to [15], extension is overseen by the Department of Natural Resources (Environmental, Land and Forestry) and the Production Department at the local district level (Agriculture, Commercial, Entomology and Veterinary).

At the district level, NAADS employs district coordinators. NAADS extension officials in lower administrative levels such as sub-county, parish, and village have been replaced with army officers (who mainly focus on input supply rather than service delivery). Individual and group trainings, demonstrations, model farmers, radio outreach programs, and farm visits are the major extension approaches employed in the project area [16].

System of government extension: Animal health (tick control, vaccination); fodder production (feed mixing, hay and silage production); crop pest and disease control; agroforestry; and cross cutting issues such as gender and climate change are among the topics covered by extension information [17].

Commercial extension initiatives have begun to provide extension services in places where they are profitable, such as high-potential areas. It entails disseminating information about and exhibiting the company's technology, such as 
hybrid seeds. Major agricultural shows are also co-financed by private firms. Due to rising rivalry in the seed, agrochemical, and dairy industries, companies have begun to provide extension guidance via stockiest, demonstrations, and field days [18].

Farmer cooperatives as essential extension intermediaries: This is done by providing economies of scale in service delivery and a vehicle for producers to communicate their desires for services, farmer organizations make extension services more affordable to small-scale farmers. Working with farmer organizations can help extension programs reach more farmers and rural families (raising efficiency), make extension activities easier to participate in (increasing effectiveness), to enhance human resources and social capital (increasing equity) [19]. Farmer groups not only assist extension in reaching members, but they also help to organize demand for extension services [20].

The farmer group role entails facilitating delivery of services, providing services to members or financing services. Farmer group approach has become popular with most extension providers in Uganda [4]. Hence, members of farmer groups are typically drawn from a village like Kayonza in Kanungu district to a locational level. The table below shows a summary of typology and major models used in Uganda with their intended audience.

Table 2. Summary of Ugandan Agriculture Extension Services, typology, dominant models and their target groups

\begin{tabular}{cccc}
\hline No & Typology of AEAS & Dominant Models Used & Target Group \\
\hline 1 & Farmers Groups & Farmer-Based Extension & Small Scale farmer \\
2 & Government Organization & Technology Transfer & Wider coverage \\
3 & Non-Governmental Organizations & Advisory Service (NAADS) & Limited area and smallholders' farmers \\
4 & Private & Commodity-Based & Literate and commercial \\
5 & Development Agencies & Integrated Project Extension & Disadvantaged groups \\
6 & Universities & Makerere University & Rural farmers around \\
\hline
\end{tabular}

Summary of Ugandan Agriculture Extension Services, typology, dominant models and their target groups. (own formulation, 2021).

\subsection{Agriculture Extension and Advisory Services Related to CSA}

Climatic-smart agriculture [21] is defined as a technique for restructuring and reorienting agricultural growth in response to changing climatic circumstances. CSA's objective of food security and development is based on three interconnected pillars: productivity, flexibility, and mitigation.

CSA is an integrative approach to address these interlinked challenges of food security and climate change that explicitly aims for three objectives:

1) Increasing agricultural production in a sustainable manner in order to achieve fair improvements in farm incomes, food security, and development;

2) Agricultural and food security systems must adapt and create resistance to climate change on several levels;

3) Agricultural greenhouse gas emissions (including crops, animals, and fisheries) reduction.

CSA urges individuals to examine these three goals in conjunction at various sizes, from local to global, and across short and long time horizons, while taking national and local problems into account [22]. To achieve these goals, farming households must modify their behavior, tactics, and agricultural practices by:

a) Improving their access to climate resilient technologies and practices, knowledge and information for increasing productivity;

b) Inputs and market data, as well as help with income diversification;

c) Organizing them better for collective action.

Rural Advisory Services in Uganda contribute to achieving climate-smart agriculture by disseminating climate information and technologies and information on production practices for climate adaption through innovative approaches, such as plant clinics [23]. In addition to the above, rural advisory services have a comparative advantage in these functions and are already actively engaged in these roles more broadly [24], to improve their effectiveness with regard to CSA will require capacity development at individual and organizational level and institutional reform at the systems level [25].

2.2.1 Sustainably increasing productivity and enhancing adaptation through technology development and information dissemination

There is a reform in extension services from transferring skills, technologies and knowledge related to the production of crops, livestock and forestry products from research to farmers, to developing technologies with farmers and catalyzing and facilitating innovation processes in Uganda [26]. Traditional extension modes (interpersonal interaction, 
demonstrations, field days, printed materials), Information and Communication Technology (ICTs) (radio, mobile phones, video, social media), rural resource centers, farmer-to-farmer extension, and farmer field school, among others, are used by Rural Advisory Services to disseminate technologies, information, and practices [27].

2.2.2 Building resilience through developing farmers' human and social capacity and providing support services

To manage the uncertainties and risks associated with climate change, diversify their agricultural and income options, and become more resilient, farmers must draw on local and scientific knowledge, sharpen their observational and experimental skills, and improve their critical thinking and problem-solving abilities to be able to make their own decisions about appropriate practices and diversified and resilient income opportunities from a menu of options [28].

Human capital refers to the skills, knowledge, and experience that an individual or population possesses, as measured by their worth or cost to an enterprise or country [29]. The rural advisory service employs non-formal education and experiential learning initiatives (such as farmer field schools, farmer learning groups, and local agricultural research committees) to boost adoption and decision-making regarding knowledge intensive agricultural practices [30].

To promote livelihood diversification, some Rural advisory services have adopted a market-oriented approach to extension by supporting farmers in the area of marketing, value addition and enterprise skills development [31].

According to [32], both men and women are active in animal waste management in order to increase agricultural output by adding it to the soil as manure, which decreases greenhouse gas emissions. Efforts to discover and execute system-level CSA treatments, rather than only plot-level interventions, have been investigated as a way to improve entire farm climate-smartness by addressing trade-offs and synergies across CSA techniques.

Climate change has been included into Uganda's national development objectives, as well as agricultural policies and programs. The creation of a National CSA Framework Program, the initiation of the agriculture sector's National Adaptation Plan process, and the formation of a national Climate Change Policy are all examples of this [33].

\subsubsection{Supporting climate change adaptation and mitigation through facilitation and brokering}

Farmers and other rural stakeholders and service providers have long relied on extension organizations to act as a "bridge" between them and service providers. Rural consulting firms are increasingly assisting agricultural innovation systems in a number of countries by taking a variety of roles in the development of multi-stakeholder innovation platforms [34]. Serving as the key innovation broker (the organization that catalyzes the innovation process and links the parties) and acting as a "bridging" organization are two examples [35].

According to [36], innovation platforms are a type of institutional innovation that can contribute to climate change adaptation and mitigation. Extension providers may aid in mitigation by bolstering farmer associations and rural organizations and connecting them to voluntary and regulated carbon markets [37].

In addition to enhancing existing ties with conventional partners, rural advisers may assist farmers connect with new types of institutions relevant to climate change, such as insurance firms. To aid innovative processes, rural advisory services and advisors require skills in areas where they typically lack, such as network creation and broking, process facilitation, and process monitoring [38].

There are various platforms such as the National Climate-Smart Agriculture Task Force and the Climate Change Department has been recognized. Continued financial and operational support to CSA coordination will be crucial to ensure complementarity and sustainability of the work of various actors [39].

\section{Innovative approaches and methods being used by different service providers for climate smart agriculture}

The following sub sections identifies and discusses some of the innovative approach and methods being used by different service providers in climate smart related extension in Uganda.

\subsection{Extension Methods for Transfer of Climate Knowledge}

To deal with changing climatic circumstances in the field or to assist farmers, different countries adopt different techniques, strategies, and methods. In Uganda, for example, National Advisory Agricultural Services aimed to improve climate change resilience through technological interventions, using an Information and Communications Technology-based (ICT-based) [40] knowledge platform in northern Uganda to improve knowledge processing, sharing, and use around climate change adaptation in agriculture, while NARO adopted the knowledge-informed, multidisciplinary, and participatory approach in western and central Uganda [41].

Climate wallpapers: This is used in many parts of Uganda to give advisory services to farmers in the form of tables or posters relating to weather forecast of agricultural activities needed to be undertaken to the local communities through display boards and this helps farmers to learn more on climate smart agricultural practices hence, increased productivity [42]. 
Using a Public Address System (PAS): Farmers are alerted about crucial climatic circumstances or agro-advisory services are provided with the use of this approach. This is a good tool for any urgent information dissemination to the villagers, such as in villages where SMS cannot be sent due to network and electrical difficulties like in Kinaba Mpungu, Kanungu district. Farmers, for example, would be notified promptly if rain was forecast for the next day so that they could schedule their farming efforts properly [43].

Table 3. Detailed smartness assessment of top continuing CSA activities by production system in Uganda

\begin{tabular}{|c|c|c|c|}
\hline No & CSA Practice & Region & Impact on CSA Pillars \\
\hline 1 & $\begin{array}{l}\text { Soil fertility control that is inte- } \\
\text { grated (Cover crops, mulching, } \\
\text { organic fertilizers) }\end{array}$ & $\begin{array}{l}\text { Central, eastern and } \\
\text { south-western humid } \\
\text { highlands }\end{array}$ & $\begin{array}{l}\text { Productivity } \\
\text { Improved yields are the consequence of water conservation and the } \\
\text { application of organic fertilizer. } \\
\text { Adaptation } \\
\text { Preserves soil moisture (water retention) and soil fertility through } \\
\text { accumulation of organic matter. } \\
\text { Mitigation } \\
\text { Maintains and/or improves soil carbon stocks and reduces external } \\
\text { input use. }\end{array}$ \\
\hline 2 & Crop rotation & Kigezi region & $\begin{array}{l}\text { Productivity; } \\
\text { In some circumstances, it contributes to product diversity and } \\
\text { boosts yields. } \\
\text { Adaptation-It helps to keep soil nutrients and moisture in check. } \\
\text { Reduces the danger of pests and diseases by improving soil fertili- } \\
\text { ty. } \\
\text { Mitigation-Soil carbon stores are maintained and/or improved. } \\
\text { When leguminous crops are introduced, the requirement for nitro- } \\
\text { gen fertilizers is reduced. }\end{array}$ \\
\hline 3 & Cover crops and green manure & $\begin{array}{l}\text { South west cattle cor- } \\
\text { ridor and Central } \\
\text { Uganda }\end{array}$ & $\begin{array}{l}\text { Productivity-Medium- to long-term soil fertility increases can lead } \\
\text { to higher yields and income. } \\
\text { Adaptation-Improves soil structure alleviating compaction and } \\
\text { erosion. Improves capacity of water retention of the soil. } \\
\text { Mitigation-Improves biomass, which may promote carbon seques- } \\
\text { tration. }\end{array}$ \\
\hline 4 & Rotational grazing & $\begin{array}{c}\text { South west and Cen- } \\
\text { tral Uganda }\end{array}$ & $\begin{array}{l}\text { Productivity } \\
\text { Increases productivity and income per unit of product. } \\
\text { Adaptation } \\
\text { Improves the soil and grass quality by reducing compaction and } \\
\text { erosion. } \\
\text { Mitigation } \\
\text { Increases the efficiency of production GHG emissions per unit of } \\
\text { product are being reduced. }\end{array}$ \\
\hline 5 & Agroforestry systems & $\begin{array}{l}\text { Central and Western } \\
\text { region }\end{array}$ & $\begin{array}{l}\text { Productivity } \\
\text { Crop diversity can help you increase your yields. Food and nutri- } \\
\text { tion security, as well as income diversification, are potential bene- } \\
\text { fits (timber, fruits). } \\
\text { Adaptation } \\
\text { Increases soil organic matter content. Improves water balance } \\
\text { (buffers the temperature). } \\
\text { Mitigation } \\
\text { Increases both above- and below-ground carbon sequestration and } \\
\text { storage. Reduced chemical inputs provide benefits. }\end{array}$ \\
\hline
\end{tabular}

Meetings of the Climate Group: Farmers are formed in groups in various regions of Uganda, such as Gulu, Kasese, Kanungu, and Kabale, to link them or to transmit climate-related information to them in a group [44]. In the community, many committees are created to take after various components, such as the Let Us Save Uganda initiative in Kabale district. A committee of such climate organizations is made up of 10-15 members, with a 40 percent to 50 percent reservation of women across the board.

Visits for exposure: These are now being undertaken for progressive farmers in the fields of Kanungu and Kasese 
district rice growers who utilize organic slurry for their crop and employ drip or sprinkle irrigation near Kibimba rice producing regions in Kasese [45]. In comparison to Rwanda and Tanzania, these exposure trips stimulate farmers to adapt these mitigation measures, resulting in proper climate smart agricultural implementation in Uganda.

Workshops on Climate Change: In Uganda, many seminars on themes such as water pond preparation, pomegranate growing, organic fertilizer usage, bespoke hiring center, and water and soil management technologies are being held to educate farmers on suitable climate wise agriculture methods [46].

Demonstration Effect Approach: The demonstration effect, also known as the progressive farmer strategy, entailed providing technical assistance [47], inputs, and credit to a chosen group of top farmers who would develop quicker and so be better able to survive difficult climatic conditions, resulting in a climate wise practice [48]. The rationale was to supplement the inadequate number of extension workers in different parts of Uganda. In a few cases there was indeed a demonstration effect where other farmers adopted the improved farmers' practices which the progressive farmers were applying [49]. However, some progressive farmers fell short of expectations; farmer selection was flawed; some farmers mishandled the demonstration inputs; and others were hesitant to pass on their expertise to other farms.

Educational and Methods approaches: These approaches focused on education of farmers and use of various extension methods to teach farmers such as training at District Farming Institutes, exposure visits, field days, radio and television programs, film shows (cinema), leaflets and posters [50]. In general, these approaches resulted in improved farming practices, productivity and production as one pillar of climate smart agriculture [51].

Training and Visit Extension and Unified Extension Approaches: Education of intermediary's personnel is important to update their knowledge related to climate change, their impacts, and consequences or on different adaptation and mitigation strategies [52]. They should improve their ability to communicate the requirements of farmer communities and look for (agro-meteorological) elements that require attention.

Climate Awareness Mass Media Campaigns: The high reach of mass extension campaign approaches is very attractive [53]. As we know, the major constraints of national extension systems are shortage of field extension personnel and limited resources to reach large numbers of farmers spread widely across geographical areas. To tackle these constraints, extension can be more efficiently performed using mass media. Extension with mass media can also be run by non-extension players (e.g., radio or television) with technical inputs through SMS from extension workers, for awareness creation or simple information delivery [54].

ICT supported farmers in adaptation and mitigation: Use of mobile phones, videos, radios etc. was done to address the issue of climate change by creating awareness among the farmers about the availability of different adaptation and mitigation strategies [55]. ICTs can strengthen the capacity of national organizations working on climate change by enabling better-informed and more participative decision-making processes. The use of ICT tools can help Ministries and development departments to coordinate actions and implement regional.

Climate Farmers Field Schools (FFS): The Farmer Field School (FFS) is a non-formal, participatory extension technique that prioritizes farmers and their needs via experience learning [24]. As a result, it provides farmers with a low-risk environment in which to experiment with new agricultural management practices, discuss and learn from their observations, allowing them to gain new practical knowledge and skills, as well as improve their individual and collective decision-making [56].

Climate-Smart Villages (CSVs): CSVs are the developed villages or models of local actions that ensure food security, promote adaptation and build resilience to climatic stresses in Uganda [57]. CSV have four components: climate information services; local knowledge and institutions; village development plans; and climate-smart technology. The emphasis is on tailoring a portfolio of interventions that complement one another and that suit the local conditions [58].

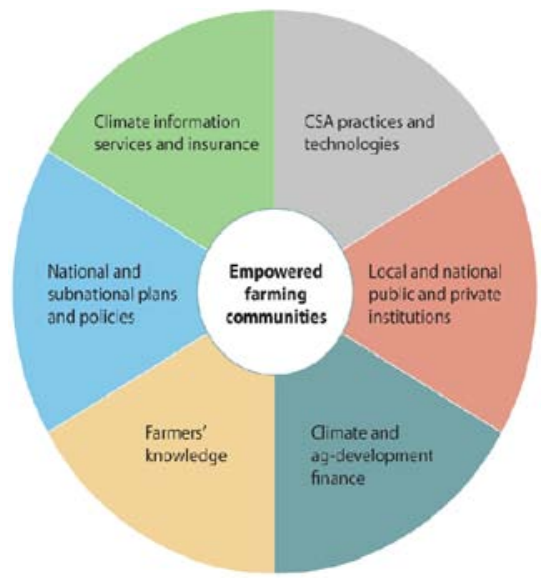

Figure 1. Key components of a CSV AR4D approach [59]. 


\section{Conclusion and Recommendations}

\subsection{Conclusion}

Basing on the background information, some extension methods and approaches identified in different regions of Uganda have been implemented but there are many more which need to be implemented to make the farmers more climate smart especially in Kigezi region because of its highlands. Therefore, climate-smart extension approaches need to be considered as part of a broader set of adaptation measures and policies for agricultural systems at a range of scales through ICT integration. CSA policies should be promoted both practices and services, such as financial services and strategies for knowledge sharing and management.

\subsection{Recommendations}

This study recommends for a strategic plan for women engagement in agriculture extension services by the Ugandan government based on priorities that reflect an understanding of economic and social costs of impaired women and factors affecting them during the adoption of CSA. Specific mechanisms for empowerment, monitoring capabilities at the community level should be established. These include supporting and strengthening the participation of local communities by all stakeholders to adopt appropriate policies about CSA for improved agriculture across the all regions in Uganda. There is need for a regulatory framework that includes a combination of appropriate CSA objectives, agriculture extension and advisory services, service providers and women empowerment.

Need for extension reforms for the long-term process of reforming and strengthening rural advisory systems, some immediate priority actions for developing climate-smart rural advisory systems and services include; establishing local-level platforms/mechanisms for better alignment and collaboration between public sector advisory services working on agriculture, water, environment, forestry and fisheries.

\section{References}

[1] D. M. Mpiima, H. Manyire, C. Kabonesa, and M. Espiling. "Gender analysis of agricultural extension policies in Uganda: informing practice?,” Gend. Technol. Dev., vol. 23, no. 2, pp. 187-205, 2019.

[2] A. Nannozi. (2019). "A case study: exploring the influence of the informal financial sector on food security among smallholder farmers in Uganda, Greater Luweero.” 2019.

[3] E. ATNR. (2018). "Report of Committee of Agriculture, Tourism and Natural Resources on the 3rd EAC peoples agriculture budget summit, held on 31st May 2018 at County Hall, Parlaiment of Kenya, Nairobi Kenya.” 2018.

[4] R. Sebaggala and F. Matovu. (2020). Effects of Agricultural Extension Services on Farm Productivity in Uganda. African Economic Research consortium, 2020.

[5] C. M. Gottschalk. (2020). “Effectiveness of climate-smart agriculture in Uganda: Evidence from micro-level data.” 2020.

[6] F. Pereira Sartori Falguera, M. A. F. Lima, V. A. S. Ferrari, G. D. C. Barriga, and E. B. Mariano. (2021). "Human Development by Gender and National Culture: A Comparative Analysis.” J. Dev. Stud., pp. 1-22, 2021.

[7] G. Oriangi, et al. (2020). "Household resilience to climate change hazards in Uganda.” Int. J. Clim. Chang. Strateg. Manag., 2020.

[8] S. LEONE 4th, “NATIONAL HUMAN DEVELOPMENT REPORT 2019,” 2019.

[9] G. Agiraembabazi, J. Ogwal, C. Tashobya, R. M. Kananura, T. Boerma, and P. Waiswa. (2021). "Can routine health facility data be used to monitor subnational coverage of maternal, newborn and child health services in Uganda?,” BMC Health Serv. Res., vol. 21, no. 1, pp. 1-10, 2021.

[10] G. W. Norton and J. Alwang. (2020). "Changes in agricultural extension and implications for farmer adoption of new practices.” Appl. Econ. Perspect. Policy, vol. 42, no. 1, pp. 8-20, 2020.

[11] M. Markou, C. A. Moraiti, A. Stylianou, and G. Papadavid. (2020). "Addressing climate change impacts on agriculture: adaptation measures for six crops in Cyprus.” Atmosphere (Basel)., vol. 11, no. 5, p. 483, 2020.

[12] R. Rupan, R. Saravanan, and B. Suchiradipta. (2018). "Climate-smart agriculture and advisory services: approaches and implication for future.” MANAGE discussion paper 1, MANAGE-Centre for Agricultural Extension ..., 2018.

[13] S. C. Mukembo and M. C. Edwards. (2015). “Agricultural extension in Sub-Saharan Africa during and after its colonial era: The case of Zimbabwe, Uganda, and Kenya.” J. Int. Agric. Ext. Educ., vol. 22, no. 3, pp. 50-68, 2015.

[14] J. Musemakweri. (2007). Farmers' experiences and perceptions of the NAADS agricultural extension system/program in Kabale district, Uganda. Iowa State University, 2007. 
[15] F. N. W. Nsubuga, K. F. Mearns, N. C. Davis, A. M. Kalumba, and K. Komen. (2021). "Exploring the influence of climate change and capital assets on livelihood formations in central region of Uganda.” Environ. Dev. Sustain., vol. 23, no. 6, pp. 9223-9242, 2021.

[16] N. Mugabi, J. Omona, and B. Jansson. (2018). “Revolutionalizing Agriculture Extension Delivery through Mobile Telephony: The Experience of Village Enterprise Agent Model in Greater Masaka Area, Uganda.” WIT Trans. Ecol. Environ., vol. 217, pp. 963-974, 2018.

[17] W. Turyahikayo and E. Kamagara. (2016). "Trust, perception and effectiveness of extension services in Uganda: A case of National Agricultural Advisory Services (NAADS).” J. Agric. Ext. Rural Dev., vol. 8, no. 11, pp. 224-231, 2016.

[18] M. L. Blum, V. R. Sulaiman, and F. Cofini. (2020). “MODULE 1: Trends in extension reform.” Agric. Ext. Transit. Worldw. Policies Strateg. reform, p. 1, 2020.

[19] Y. Nakano, T. W. Tsusaka, T. Aida, and V. O. Pede. (2018). "Is farmer-to-farmer extension effective? The impact of training on technology adoption and rice farming productivity in Tanzania.” World Dev., vol. 105, pp. 336-351, 2018.

[20] T. Wossen, et al. (2017). "Impacts of extension access and cooperative membership on technology adoption and household welfare.” J. Rural Stud., vol. 54, pp. 223-233, 2017.

[21] N. N. Charles and B. E. Onkundi. (2021). "Determination of Adoption of Organic \& AMP; Conventional Farming and Climatic Smart Agricultural Practises among Smallholder Farmers in Nyaribari Chache Sub-County, Kisii County, Kenya.” Recent Prog. Plant Soil Res., Vol. 2, pp. 58-72, 2021.

[22] V. Zavratnik, D. Podjed, J. Trilar, N. Hlebec, A. Kos, and E. Stojmenova Duh. (2020). "Sustainable and community-centred development of smart cities and villages.” Sustainability, vol. 12, no. 10, p. 3961, 2020.

[23] V. Okuna and D. Mwesigwa. (2021). “'From rain-fed farms to irrigated farms’: Irrigation technology for smart farming in Lira city, mid-north Uganda,” 2021.

[24] J. J. L. Osumba, J. W. Recha, and G. W. Oroma. (2021). “Transforming Agricultural Extension Service Delivery through Innovative Bottom-Up Climate-Resilient Agribusiness Farmer Field Schools.” Sustainability, vol. 13, no. 7, p. 3938, 2021.

[25] E. D. Raile, L. M. Young, J. Kirinya, J. Bonabana-Wabbi, and A. N. W. Raile. (2021). "Building Public Will for Climate-Smart Agriculture in Uganda: Prescriptions for Industry and Policy.” J. Agric. Food Ind. Organ., vol. 19, no. 1, pp. 39-50, 2021.

[26] E. L. Ampaire, et al. (2017). "Institutional challenges to climate change adaptation: A case study on policy action gaps in Uganda,” Environ. Sci. Policy, vol. 75, pp. 81-90, 2017.

[27] F. O. Amadu, D. C. Miller, and P. E. McNamara. (2020). "Agroforestry as a pathway to agricultural yield impacts in climate-smart agriculture investments: Evidence from southern Malawi.” Ecol. Econ., vol. 167, p. 106443, 2020.

[28] S. H. Shah, L. C. Angeles, and L. M. Harris. (2017). "Worlding the intangibility of resilience: The case of rice farmers and water-related risk in the Philippines.” World Dev., vol. 98, pp. 400-412, 2017.

[29] R. Eriksson and M. Rataj. (2019). "The geography of starts-ups in Sweden. The role of human capital, social capital and agglomeration.” Entrep. Reg. Dev., vol. 31, no. 9-10, pp. 735-754, 2019.

[30] J. Jacobi, et al. (2018). “Operationalizing food system resilience: An indicator-based assessment in agroindustrial, smallholder farming, and agroecological contexts in Bolivia and Kenya.” Land Use Policy, vol. 79, pp. 433-446, 2018.

[31] D. Martinez-Baron, G. Orjuela, G. Renzoni, A. M. L. Rodríguez, and S. D. Prager. (2018). “Small-scale farmers in a 1.5 C future: The importance of local social dynamics as an enabling factor for implementation and scaling of climate-smart agriculture.” Curr. Opin. Environ. Sustain., vol. 31, pp. 112-119, 2018.

[32] E. M. Kikulwe, et al. (2018). "Does gender matter in effective management of plant disease epidemics? Insights from a survey among rural banana farming households in Uganda.” J. Dev. Agric. Econ., 2018.

[33] M. Acosta, S. van Bommel, M. van Wessel, E. L. Ampaire, L. Jassogne, and P. H. Feindt. (2019). "Discursive translations of gender mainstreaming norms: The case of agricultural and climate change policies in Uganda.” In Women's Studies International Forum, 2019, vol. 74, pp. 9-19.

[34] M. Sowman and X. Rebelo. (2022). "Sustainability, Disaster Risk Reduction and Climate Change Adaptation: Building from the Bottom Up-A South African Perspective from the Small-scale Fisheries Sector.” In Creating Resilient Futures, Palgrave Macmillan, Cham, 2022, pp. 151-181.

[35] D. F. McGonigle, et al. (2020). “A knowledge brokering framework for integrated landscape management.” Front. Sustain. Food Syst., vol. 4, p. 13, 2020.

[36] A. Bussler and L. Schmidt. (2019). "The role knowledge brokerage in local climate change mitigation policy in Portugal The case of BEACON,” 2019.

[37] M. Yomo, G. B. Villamor, M. Aziadekey, F. Olorunfemi, and K. A. Mourad. (2020). "Climate change adaptation in semi-arid ecosystems: A case study from Ghana.” Clim. Risk Manag., vol. 27, p. 100206, 2020. 
[38] P. Berry, P. M. Enright, J. Shumake-Guillemot, E. Villalobos Prats, and D. Campbell-Lendrum. (2018). “Assessing health vulnerabilities and adaptation to climate change: a review of international progress,” Int. J. Environ. Res. Public Health, vol. 15, no. 12, p. 2626, 2018.

[39] D. B. Namanya, et al. (2021). “Geography, Climate Change and Health Adaptation Planning in Uganda.” In Practicing Health Geography, Springer, 2021, pp. 175-190.

[40] G. Farrell. (2007). "Survey of ICT and education in Africa: Uganda country report,” 2007.

[41] S. Franzel, E. Kiptot, and A. Degrande. (2019). "Farmer-to-farmer extension: A low-cost approach for promoting climate-smart agriculture.” In The climate-smart agriculture papers, Springer, Cham, 2019, pp. 277-88.

[42] O. Westermann, W. Förch, P. Thornton, J. Körner, L. Cramer, and B. Campbell. (2018). "Scaling up agricultural interventions: Case studies of climate-smart agriculture.” Agric. Syst., vol. 165, pp. 283-293, 2018.

[43] D. Ninsiima. (2015). “'Buuza Omulimisa'(ask the extension officer) text messaging for low literate farming communities in rural Uganda.” In Proceedings of the Seventh International Conference on Information and Communication Technologies and Development, 2015, pp. 1-4.

[44] T. E. Epule, J. D. Ford, S. Lwasa, B. Nabaasa, and A. Buyinza. (2018). "The determinants of crop yields in Uganda: what is the role of climatic and non-climatic factors?,” Agric. Food Secur., vol. 7, no. 1, pp. 1-17, 2018.

[45] C. Roncoli, B. E. N. Orlove, and M. R. Kabugo. (2010). “Terms of change: How farmers in Uganda talk about climate change.” 2010.

[46] H. Nyantakyi-Frimpong. (2019). "Combining feminist political ecology and participatory diagramming to study climate information service delivery and knowledge flows among smallholder farmers in northern Ghana,” Appl. Geogr., vol. 112, p. 102079, 2019.

[47] P. Zhang and J. Hong. (2021). "Education, Local Financial Investment and Rural Financial Repression: Learn from the US's Demonstration Effect on China,” CONVERTER, vol. 2021, no. 7, pp. 27-36, 2021.

[48] M. Taylor and S. Bhasme. (2018). "Model farmers, extension networks and the politics of agricultural knowledge transfer.” $J$. Rural Stud., vol. 64, pp. 1-10, 2018.

[49] S. H. Eriksen, L. K. Cramer, I. Vetrhus, and P. Thornton. (2019). "Can climate interventions open up space for transformation? Examining the case of climate-smart agriculture (CSA) in Uganda.” Front. Sustain. Food Syst., vol. 3, p. 111, 2019.

[50] K. Davis. (2019). “The complex processes of agricultural education and extension.” Taylor \& Francis, 2019.

[51] G. Akumu, et al. (2019). "The influence of extension approaches on uptake of postharvest technologies among maize farmers in Uganda,” African J. Rural Dev., vol. 3, no. 4, pp. 955-971, 2019.

[52] P. B. Rwamigisa, R. Birner, M. N. Mangheni, and A. Semana. (2018). "How to promote institutional reforms in the agricultural sector? A case study of Uganda’s National Agricultural Advisory Services (NAADS),” Dev. Policy Rev., vol. 36, no. 5, pp. 607-627, 2018.

[53] E. Wassajja. (2017). "Governance challenges in post-conflict agricultural recovery programs in Northern Uganda: a comparative study of the Northern Uganda Social Action Fund (NUSAF) and the National Agricultural Advisory Services (NAADS),” 2017.

[54] A. Belay, J. W. Recha, T. Woldeamanuel, and J. F. Morton. (2017). “Smallholder farmers' adaptation to climate change and determinants of their adaptation decisions in the Central Rift Valley of Ethiopia.” Agric. Food Secur., vol. 6, no. 1, pp. 1-13, 2017.

[55] P. K. Gangopadhyay, A. Khatri-Chhetri, P. B. Shirsath, and P. K. Aggarwal. (2019). "Spatial targeting of ICT-based weather and agro-advisory services for climate risk management in agriculture.” Clim. Change, vol. 154, no. 1, pp. 241-256, 2019.

[56] D. Mfitumukiza, et al. (2017). "Assessing the farmer field schools diffusion of knowledge and adaptation to climate change by smallholder farmers in Kiboga District, Uganda.” J. Agric. Ext. Rural Dev., vol. 9, no. 5, pp. 74-83, 2017.

[57] O. Bonilla Findji, J. W. M. Recha, M. A. O. Radeny, and P. Kimeli. (2017). "East Africa Climate-Smart Villages AR4D Sites: 2016 Inventory,” 2017.

[58] I. G. L. Vetrhus. (2019). “Agricultural transformation through Climate-smart agriculture: a study on power relations in the climate-smart villages of Hoima District, Uganda.” Norwegian University of Life Sciences, Ås, 2019.

[59] P. K. Aggarwal, et al. (2018). "The climate-smart village approach: framework of an integrative strategy for scaling up adaptation options in agriculture.” 2018. 